\title{
INNOVATIVE ACTIVITIES OF AGRICULTURAL CONSULTATIVE NETWORKS AS A FACTOR IN STRENGTHENING THE ECONOMY OF RURAL AREAS OF UKRAINE
}

\author{
Valentyn Martynenkov \\ Taras Shevchenko National University of Kyiv \\ 64/13 Volodymyrska str., Kyiv, Ukraine, 01601 \\ ibeerless@gmail.com
}

\begin{abstract}
The article highlights the scientific substantiation of perspective ways of innovative development of national agricultural advisory services in the context of stimulating economic development in rural areas of Ukraine in the conditions of decentralization of power. The study allowed to establish the existing imbalance in the ratio of the main types of agricultural enterprises and agricultural service cooperatives, falling on one advisory service, as well as to determine the causes of significant imbalances in the regional context, the determination of which offers a number of key innovation priorities, activating the integration of education, research, marketing, economic and financial, consulting and other services necessary to provide a complete infrastructure of the economy of rural areas with the potential of basic institutions of NAAS and MES.

Keywords: agricultural advisory service, economy of rural areas, innovative development, innovation, advisory and consulting services, agricultural enterprises.

\section{Introduction}

The global experience of the development of advisory services of economic entities of rural areas highlights the importance of creating the efficient regional network of information and advisory service based on innovation technologies with regard to service delivery to small farm enterprises (FE), family farm enterprises (FFE), private farm enterprises (PFE) and other agricultural enterprises, which is an essential factor in the system of strengthening food and socio-economic security of each developed country. However, the development of domestic agricultural consultative network is characterized by certain dualism. On the one hand, we have around a third of Ukrainian rural population, 4 million private farm enterprises and almost 40 thousand officially registered farm enterprises in need of government support, particularly in the area of professional consultative service delivery, and on the other hand, a number of highly profitable fields of agricultural production (in the first instance, crop growing, poultry breeding etc.) are under full control and dependent on the policy of huge agricultural holdings. Their vast majority is transnational companies having their own consulting companies and the need for advisory services according to Law of Ukraine On agricultural advisory service is questionable. In this regard, the need arises to study the evolution of national agricultural advisory services and determine perspective ways of innovative activities of agricultural consultative networks in Ukraine.
\end{abstract}

\section{Analysis of recent studies and publications}

The general problems hampering the robust development of advisory and consulting services in different financial and economic aspects are being studied in many scientific centres of Ukraine and the world. Among others, we can point out the research works of such economic scientists [1-7]. In international studies, the issue related to importance of agricultural advisory services is not controversial because specialized consulting firms have long been regarded as the main driving force of promoting the innovations in the agricultural production at the inter-regional and national level. Moreover, most of publications chiefly concern the determination of scientific projects related to "institutional environment of consulting services for agriculture; determination of the structure required for the operation of the advisory system as well as approaches, methods, tools and content of consultative activities etc." [8-11]. In [12-19] were formed the methodology elements of creating an innovative platform for cooperation between scientists, government officials and business. 
However, in Ukraine the subject of consulting service delivery for agricultural enterprises is not scientifically highlighted enough, especially in the area of innovative development of agricultural advisory services.

\section{The aim and objectives of research}

The article is to highlight the theoretical and methodological problems of formation of conditions for innovative activities of agricultural consultative networks as in context of strengthening the economy of rural areas of Ukraine.

To achieve this goal the following tasks were set:

1. Scientific substantiation of perspective ways of innovative development of national agricultural advisory services to boost the economy of rural areas in the conditions of decentralization of power and upgrade of the system of the National Academy of Agrarian Sciences of Ukraine.

2. Detected significant imbalance in the ratio of farming enterprises, private farming enterprises and agricultural service cooperatives per advisory service, residual principle of financing as well as absence of mechanisms of mutually effective cooperation of the agricultural consultative networks with local self-government bodies are the main reasons slowing down the pace of rural development. In this regard, one of the key strategic priorities is to choose the innovative way of solving the above-mentioned issues through more active integration of educational programs.

\section{Materials and methods of research}

The theoretical basis of the study was the fundamental position of leading scientists in the field of rural development and extension services in agriculture. The normative legal documents of strategic nature were used. Methodological research framework is covering general scientific principles and methods of knowledge, analysis, synthesis, specifically inductive, deductive abstract, dialectical, system, functional, task-targeted, synergistic method and SWOT-analysis.

\section{Research results}

Given the definition of consulting services as the process of financial and economic consulting at the local level (financial analysis, accounting, audit, taxation) and at the global level (strategic development, reorganization, innovation process), one of the main official documents related to the consultation of the network of agricultural enterprises is Law of Ukraine On agricultural advisory activities (see the details, for example, in [1] and [12]). Besides, it is pertinent to single out a number of productive research studies of the national scientific centre of the Institute of Agrarian Economics of the National Academy of Sciences of Ukraine scientifically substantiating that the "advisory service is the key element of the system of dissemination of agricultural knowledge" [13], and constructively formulating the basic organizational and methodological principles of monitoring the delivery of socially oriented agricultural advisory services significantly streamlining the organization of work related to "...implementation of the State target program on the agricultural advisory activity and plans (programs) developed for its implementation, aimed at the delivery of socially oriented advisory services in Ukrainian regions (oblast) in line with: the State target program on the development of Ukrainian rural areas for the period until 2015" [2].

The importance of outlined issues in the context of the EU integration aspirations of Ukraine is stressed with the fact that the Council of Europe sets high priority for the government support to state agricultural services. Alongside with that, the State budget of Ukraine for 2015/2016 does not provide for the funds to finance the state target program on the agricultural advisory activity, delivery of socially oriented advisory services despite the direct obligations stipulated by Article 8 of Law of Ukraine On agricultural advisory activity [2]. Furthermore, according to the data of the National Institute for Strategic Studies (NISS), in the context of implementation of measures stipulated by the State target program on the development of Ukrainian rural areas in terms of advisory support, we have that “...during 2008 - 20117 million hryvnias were actually used from the state budget or 15.6 percent of the forecast volume, in particular in $2008-3487.6$ thousand hryvnias (33 percent of the planned volume), in 2009 - 1863 thousand hryvnias (17.3\%), in 2010 - 1659.4 thousand hryvnias (14.9\%). In 20121600 thousand hryvnias were used from the 
state budget out of the planned 2 million hryvnias, and in 2011 and 2013 the funds were not allocated for the government support to the agricultural advisory service" [3].

The comprehensive analysis of the current financial and economic situation in Ukraine is indicative of almost zero probability of improvement of the government financial support to advisory services for domestic agricultural enterprises. In this regard, it is proposed to actualize the experience of well-known consulting firms whose number was 1251 units as of 31.12.2013 according to the data of the Audit Chamber of Ukraine, and "in Ukraine as a whole the number of auditing firms and auditors entitled to carry out audit activities and having relevant obligation to submit the report to the Audit Chamber of Ukraine under form No. 1 - audit was 1488 entities" [14].

The analysis of the statistic data characterizing the scope of delivered services with regard to tasks aimed at giving confidence to economic entities in the field of agriculture, hunting, forestry, fishing and fish breeding indicates the need for additional consideration of the reasons which caused the fact that in 2013 Kirovohradska Oblast suddenly became an absolute leader having delivered the services (exclusive of VAT) in the amount of 50 million UAHs (91 percent of all operations), but Kyivska Oblast (including the capital city) turned into an outsider [14]. Even if we assume that we are dealing with a technical error, because Kyivska Oblast has most of audit organizations and in 2012 the relevant services were delivered in the amount of 49 million UAHs, however, it confirms hyper-high level of centralization of consulting services for economic entities in the field of agriculture, hunting, forestry, fishing and fish breeding as the lion's share of all operations in Ukraine is systematically performed in one region.

It is pertinent to lay a special emphasis on the importance of continuing the technical assistance project launched in 1996 in the framework of bilateral agreements between Ukraine and Germany DGRV/GIZ "Support to rural finance in Ukraine", whose implementation phases should be agreed with the operation of the network of domestic agricultural consultative networks as well as Swiss-Ukrainian project DESPRO greatly supporting the decentralization of power in Ukraine. It will allow for considerable minimization of risks in economic and administrative activities in newly established rural communities and stimulate socio-economic rural development in Ukraine.

The analysis of studies results of leading scientific centres of Ukraine and the world shows that the economic success of most of developed countries of the world greatly depends on the development of the market of consulting services. In particular, K. Kowalska proves that the income distribution between different types of services boosts the growth of German business consulting market by $16.4 \%$ in 2012 in comparison with 2010 and the total income of management consulting in Europe was over 90 billion Euros in 2012 [15]. Moreover, in 2015/2016 the consulting industry keeps developing rapidly with a clear trend to income increase [18].

In this regard, we will systematize the work experience of the most successful consulting companies (Deloitte, PricewaterhouseCoopers, Ernst\&Young and others) and define the priorities of the innovative development of the market of consulting services in Ukraine for agricultural enterprises (Table 1).

Thus, based on such SWOT-analysis, we can outline two possible strategic innovative ways of innovation activities of agricultural consultative network on the basis of:

1) private consulting companies;

2) state research establishments of the system of the National Academy of Agrarian Sciences and Ministry of Education of Ukraine.

Besides, if the delivery of consulting services for large agricultural enterprises (corporations, agricultural holdings etc.) is fully regulated by market economy laws, it is necessary to develop a flexible system of tax incentives allowing for considerable reduction of the cost of relevant advisory services for the stimulation of the development of consulting industry in favor of small agricultural producers.

Furthermore, it is necessary to make the most of existing regional potential of the agricultural consultative network which is, however, distributed in Ukraine unevenly in relation to existing PFEs, FEs, agricultural service cooperatives (ASC) etc. (Fig. 1) 
Table 1

SWOT-analysis of innovative areas of market development of consulting services for agricultural enterprises of Ukraine

\section{Small and medium enterprises}

Large companies (agricultural holdings, TNC)

1. Globalization and computerization of the market of technologies of modern agricultural production.

1. Development of the network of small and medium enter- 2. Increase in demand for the development of global innovaprises in newly established rural communities requiring the tion strategies for the development of the territories, sociodevelopment of modern investment projects based on innova- economic clusters, transnational companies, agricultural tive agricultural technologies.

holdings etc.

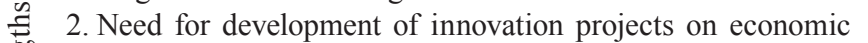
development of territorial communities to be financed from the cast of optimal size of agricultural land areas (by types of proState Fund for Regional Development in terms of decentraliza- duction) profitable for the enterprises' lease or purchase (after tion of power, as well as from other non-government sources. lifting the relevant moratorium and with due consideration of 3. Development of the market of domestic agricultural coop- amendments to national regulatory acts). eration.

4. Optimization of tax burden (especially in the area of transfer pricing).

5. High solvency of consumers of consulting services

6. Hyper-fast development of outsourcing services

1. Lack of most of entrepreneurs' experience and traditions to 1. Poor controllability of the market of consulting services at use consulting services for innovative development of agriculW tural enterprises.

2. Stereotype on high cost of consulting services.

3. Low solvency of consumers of consulting services.

the legislative level.

2. Frequent change of the Ukrainian legislative framework.

3. Asymmetry of administrative goals and tasks as well as methods of their solving.

4. Low computer literacy of rural population engaged in agri- 4. Absence of competent companies having sufficient level of cultural production. experience in service delivery to big agricultural business.

. Diversification of the market, portfolio and dimension of consulting services.

2. Collaboration with financial and economic units of newly established territorial communities on delivery of advisory services.

1. High level of corruption of government authorities and other institutions.

ש 2. Shadow domestic economy, particularly, in terms of government support to innovative development of the network of agri-

$\exists$ cultural companies different by size as well as other types of rural economy (especially tourist and recreation area).

3. Unpredictable national financial and economic policy (hyperinflation, permanent change of Tax and Customs codes etc.).

Source: drafted by the author [4-10]

Therefore, it was found out that the average indicators of burden per advisory service in Ukraine were more than 265 units of FE and 28 thousand units of PFEs and all regions of the country could be conditionally divided into the following groups (Table 2).

Table 2

Grouping of Ukrainian regions by level of burden per advisory service of the FE and PFE

\begin{tabular}{cccccc}
\hline \multirow{2}{*}{ Group } & \multicolumn{1}{c}{ FE } & & \multicolumn{2}{c}{ PFE } \\
\hline \multirow{2}{*}{ I } & Region & Unit & Group & Region & Unit \\
& Mykolayivska Region & 3860 & \multirow{2}{*}{ I } & Dnipropetrovska Region & 175,4 \\
& Dnipropetrovska Region & 3348 & & Volynska Region & 154,2 \\
& Chernihivska Region & 88,85714 & & Chernihivska Region & 22,81429 \\
II & Chernivetska Region & 83,75 & II & Chernivetska Region & 21,875 \\
& AR of Crimea & - & & Donetska Region & 21,78
\end{tabular}

Source: drafted by the author based on Fig. 1 


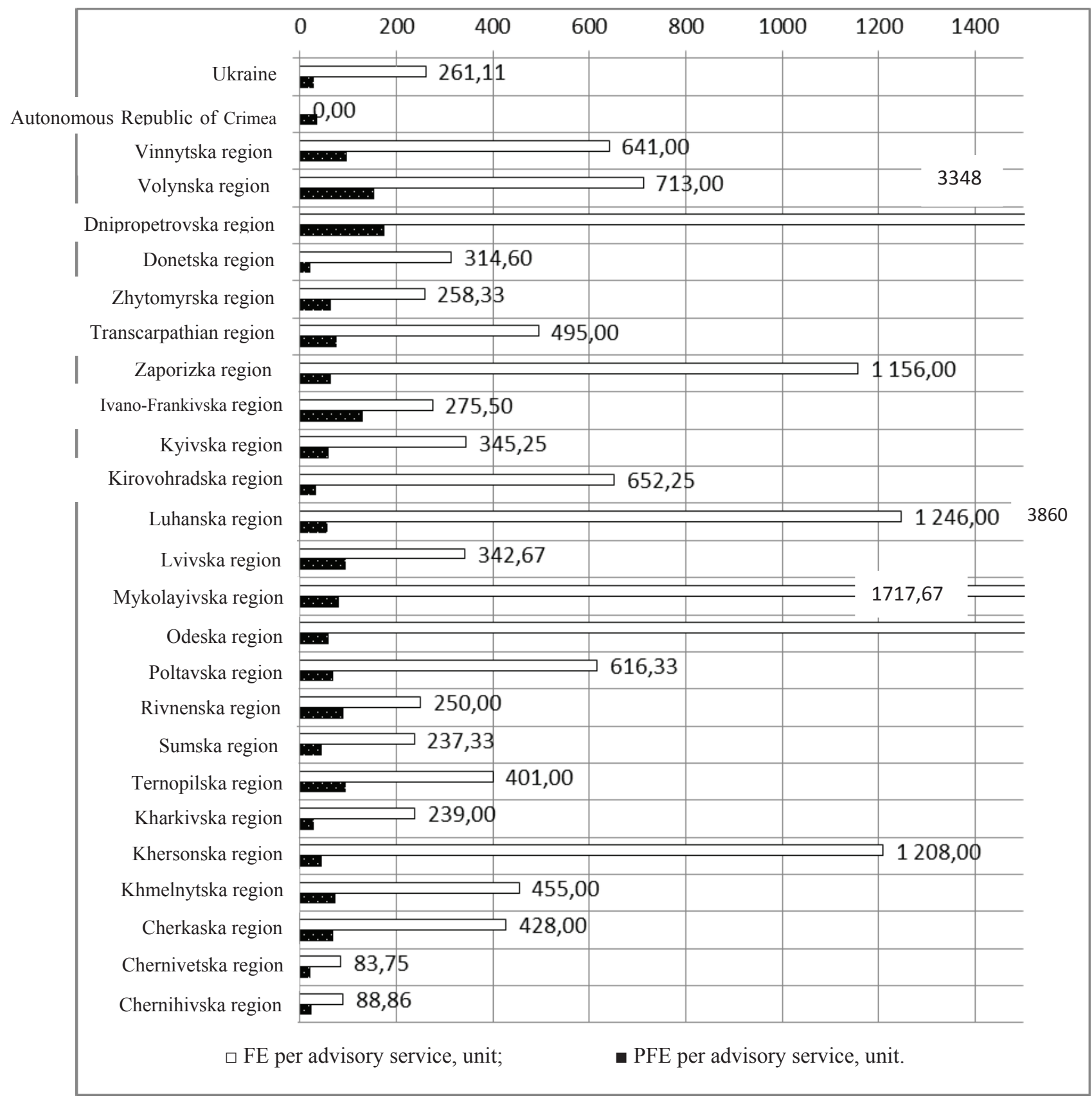

Fig. 1. Ratio of FEs and PFEs per advisory unit as of 2014/2015

Source: calculated by the author based on the official data of the Ministry of Agrarian Policy and Food of Ukraine [16]

The analysis of the data set out in Table 2 points out the need for priority support to those regions of the country, which are in group I because the indicators are several orders better in group II. Moreover, Dnipropetrovska Region has the highest burden per advisory service both for $\mathrm{FE}$ and for PFE denoting the priority of extension of the consultative network in this region because the presence of five registered agricultural experts-advisors is far from being enough. The similar situation occurred in Ukraine regarding the service delivery to ASC (Table 3).

Give the regional disproportions of the agricultural consultative network defined above, we share the viewpoint expressed by All-Ukrainian non-government organization "National associ- 
ation of agricultural consultative networks of Ukraine" regarding the expediency of establishing "the National Center of Agricultural Advisory Service", whose existence is stipulated by special order of the Cabinet of Ministers of Ukraine (of May 23, 2012 No. 303-r.), which was not implemented due to complicated financial as well as military and political situation [17].

Table 3

Grouping of Ukrainian regions by levels of service delivered by one advisory service to ASC (as of 2014/2015)

\begin{tabular}{ccc}
\hline Group & Region & Number of ASC being served by 1 advisory service \\
\hline I & Luhanska Region & 53 \\
& Mykolayivska Region & 41 \\
& Zaporizka Region & 40 \\
Lvivska Region & 5 \\
II & Zhytomyrska Region & 5 \\
& Chernivetska Region & 3
\end{tabular}

Source: calculated by the author based on the official data of the Ministry of Agrarian Policy and Food of Ukraine [16]

In order to find alternative ways of development of the innovative activities of the agricultural consultative networks in strengthening the rural economy of Ukraine, it is proposed to take into account the financial possibilities stipulated by the Cabinet of Ministers of Ukraine to support the processes of decentralization for 2016, in particular, provide in the budget program of the State Fund for Regional Development (which received over 3 billion UAHs for its implementation) the expansion of the procedure for the preparation, evaluation and selection of investment programs and projects on regional development to be implemented at the expense of the State Fund for Regional Development (Resolution of the Cabinet of Ministers of Ukraine of March 18, 2015 No. 196 [18]). In particular: investment programs and project should be compliant not only with the priorities defined in the State Regional Development Strategy, strategies on development of regions and launch of investment programs, projects related to cooperation of territorial communities etc. but also contribute to the development of domestic agricultural advisory service (especially at the educational and scientific institutions of the National Academy of Agrarian Sciences and Ministry of Education and Science of Ukraine).

In this context, it is important to organize the cooperation of higher educational establishments of Ukraine specialized in agriculture (where 166.4 thousand students study as of January 01,2016$)$, particularly, regarding the teaching practice in the area of delivery of agricultural advisory services to FE, PFE and ASC. The simultaneous involvement of specialists of leading national research centres in the field of agriculture (particularly, over 4.4 thousand scientists work within the system of the National Academy of Agrarian Sciences, 340 of them are doctors of sciences and academicians) will allow to solve a number of issues related to business planning, determination of optimal types of high quality types of agricultural products and agricultural technologies with due consideration of specific natural and climatic conditions. It will provide for practical implementation of the developed theories of social models of complex rural and agricultural development.

\section{The discussion of the results}

Thus, the author was the first to compare rates of decentralization of power and quality of innovation advisory services in agriculture Ukraine. 
The results are appropriate to be used in socio-economic activities of the newly established municipalities to form innovative development strategy, the availability of which provides relevant regulatory documents, including passport economic community.

This publication is launching a new scientific field studies, including for the purpose of writing a thesis in assessing the impact of innovation and consulting services to the level of agricultural development and national economy in general.

\section{Conclusions}

Given the fact that the theory of market economy a priori provides for cyclic existence of different phases of the development of farming enterprises, in particular, crises, whose management is, in our view, possible subject to delivery of professional advisory services combining the following innovative ways:

1) enhancement of the production efficiency at the expense of agricultural innovations;

2) activation of outsourcing services;

3) increase in the innovative level of staffing;

4) development of long-term market strategy of the innovative rural development based on the principles of sustainability.

The detected significant imbalance in the ratio of farming enterprises, private farming enterprises and agricultural service cooperatives per advisory service, residual principle of financing as well as absence of mechanisms of mutually effective cooperation of the agricultural consultative networks with local self-government bodies are the main reasons slowing down the pace of rural development. In this regard, one of the key strategic priorities is to choose the innovative way of solving the above-mentioned issues through more active integration of educational, scientific, marketing, financial and economic and other services at the institutions of the National Academy of Agrarian Sciences and Ministry of Education and Science of Ukraine with due consideration of main principles of commercialization of scientific research results aimed at strengthening the socio-economic security of rural areas of Ukraine.

\section{References}

[1] Verba, V. A., Reshetnyak, T. I. (2000). Orhanizatsiya konsaltynhovoii diyalnosti. Kyiv: National Economic University, 228.

[2] Kropyvko, M. F. (2010). Orhanizatsiyno-metodychni rekomendatsii z monitoryngu nadannya sotsialno spryamovanykh silskohospodarskykh doradchykh posluh. Kyiv: Institute of Agrarian Economics National Scientific Centre of the National Academy of Agrarian Sciences of Ukraine, 39.

[3] Zhuravska, L .A. Shchodo derzhavnoi pidtrymky rozvytku silskohospodarskoho doradnytstva v Ukraiini. National Institute for Strategic Studies. Available at: http://www.niss.gov.ua

[4] Korinets, R. Ya. (2003). Silskohospodarske doradnytstvo. Kyiv: Institute of Rural Development, 450.

[5] Silskohospodarske doradnytstvo u sviti. Available at: http://www.dorada.org.ua/na-dopomogu-doradniku/silskogospodarske-doradnitstvo-u-sviti.htm

[6] Borodina, O. M.; Sabluk, P. T., Ambrosov, V. Ya., Maznev, H. Ye. (Eds.) (2001). Doradnytstvo yak osnova rozvytku pidpryyemnytstva u silskomu hospodarstvi. Kyiv: Institute of Agrarian Economics, 808-810.

[7] Kalna-Dubinyuk, T. P. Kropyvko, M. F., Bezkrovnyi, M. F., Kryvoruchko, I. M. (2006). Osnovy agrarnoho konsaltynhu. Kyiv: Education book, 224.

[8] Faure, G., Desjeux, Y., Gasselin, P. (2012). New Challenges in Agricultural Advisory Services from a Research Perspective: A Literature Review, Synthesis and Research Agenda. The Journal of Agricultural Education and Extension, 18 (5), 461-492. doi: 10.1080/1389224x.2012.707063

[9] Birner, R., Davis, K., Pender, J., Nkonya, E. Anandajayasekeram, P. et al. (2006). From "best practice" to "best fit": a framework for designing and analyzing pluralistic agricultural advisory services. Available at: https://ideas.repec.org/p/fpr/resbrf/4.html doi:10.2499/bestfitibrb04 
[10] Benin, S., Johnson, M. Abokyi, E., Ahorbo, G., Jimah, K. et. al. (2014). Revisiting agricultural input and farm support subsidies in Africa: The case of Ghanaâ s mechanization, fertilizer, block farms, and marketing programs. SSRN Electronic Journal. Available at: https://papers.ssrn.com/sol3/papers.cfm?abstract id $=2373185$ doi:10.2139/ssrn. 2373185

[11] Pender, J., Gebremedhin, B., Benin, S., Ehui, S. (2001). Strategies for Sustainable Development of Less-Favoured Areas: Strategies for Sustainable Agricultural Development in the Ethiopian Highlands. American Journal of Agricultural Economics, 83 (5), 1231-1240. doi: 10.1111/0002-9092.00272

[12] Zakon Ukrayiny № 1807-IV. (2004). Pro silskohospodarchu doradchu diyalnist. Available at: http://zakon3.rada.gov.ua/laws/show/1807-15

[13] Korinets, R., Lupenko, Yu., Kropyvko, M. et al. (Eds.) (2013). Silskohospodarske doradnytstvo: problemy, stratehiya ta shlyakhy rozvytku. Kyiv: Institute of Agrarian Economics National Scientific Centre, 152.

[14] Uzahalnena informatsiya pro stan audytorskoii diyalnosti v Ukraiini u 2013 rotsi (2014). Audytorska palata Ukrayiny, 49. Available at: http://www.apu.com.ua/files2/zvit_2013.doc

[15] Kowalska, K. (2014). Stan i perspektyvy rozvytku rynku konsaltynhovykh posluh Nimechchyny u konteksti zahalnoyevropeyskykh tendentsiy. Bulletin of Taras Shevchenko Kyiv National University. Economics, 8 (161), 26-30.

[16] Informational and Analytical Papers of the Ministry of Agrarian Policy and Food of Ukraine (2016). Available at: http://minagro.gov.ua nya.html

[17] DORADA (2016). Available at: http://dorada.org.ua/nasha-diyalnist/analitika-doslidzhen-

[18] Decentralizaciya vlady (2016). Available at: http://decentralization.gov.ua/news/item/id/1490

[19] Zalizko, V. (2016). Methodology of creating an innovative platform for cooperation between scientists, government officials and business. Polska: Puławy, 77-80. 